\title{
Annual Report on External Quality Assessment Scheme for Immunoassay Tests in Korea (2014)
}

Hyon-Suk Kim and Young Lan Kim, as Immunoassay Subcommittee, Korean Association of External Quality Assessment Service

Department of Laboratory Medicine, Yonsei University College of Medicine, Seoul, Korea

\section{Corresponding author:} Hyon-Suk Kim

Department of Laboratory Medicine, Yonsei University College of Medicine, 50-1 Yonseiro, Seodaemun-gu, Seoul 03722, Korea

Tel: $+82-2-2228-2443$

Fax: +82-2-364-1583

E-mail: kimhs54@yuhs.ac

pISSN: 2384-2458

elSSN: 2288-7261
In 2014, two external quality assessment trials were performed on 13 test items grouped in four categories. The laboratories procured the materials for the first and second trials on 13 May 2014 and 11 November 2014, respectively. The trials were performed on 13 test items, including tumour markers, thyroid hormones, cardiac marker troponin (troponin $\mathrm{T}$ or troponin I), and procalcitonin as a new biomarker for immunoassay methods. The bone marker carboxy-terminal collagen crosslinks (CTX) has been replaced by procalcitonin this year because only a limited number of institutions used it. External quality surveys of the 13 immunoassay test items with 8 control materials were performed as scheduled. The 13 control materials included six tumour markers, alpha-fetoprotein, carcinoembryonic antigen, carcinoma antigen 125, carbohydrate antigen 19-9, human chorionic gonadotrophin, and prostate specific antigen, as well as five thyroid markers, thyroid hormone 3 (T3), T4, thyroid stimulating hormone, free $\mathrm{T} 4$, and thyroglobulin. This year, procalcitonin has been introduced as a new biomarker in addition to troponin, which was introduced last year. Five homemade pooled sera and three commercial control sera were used as survey materials. The MAS Tri-point Liquimmune level 3 (Medical Analysis Systems Inc., USA) was used for controls of thyroid hormones, while Elecsys PreciControl Varia and Elecsys PreciControl Troponin (Roche, Germany) were used for controls of the new biomarkers procalcitonin and troponin, respectively. In the external quality assessment by the Immunoassay Subcommittee, 712 institutions participated in the first trial survey (response rate 97.9\%), while 715 participated in the second survey (response rate $97.9 \%$ ). The quality of the participating laboratories seems to be continuously improving compared to the results of their peers. Additionally, this year procalcitonin has been introduced as a new biomarker instead of the CTX, which was used in 2013, while thyroglobulin and troponin-T/troponin-I, which were used for the 2013 samples, continue to be used in surveys by the Immunoassay Subcommittee.

(J Lab Med Qual Assur 2015;37:190-208)

Key Words: Immunoassay, Quality assurance, External quality assessment, Survey, Tumour marker, Thyroid marker, Cardiac marker, Procalcitonin

\section{서론}

전년도에 이어 2014년도에도 2회의 외부정도관리 신빙도 조사사업을 실시하였다[1]. 각 회당 8개씩의 관리물질들을 냉 장택배로 우송하였고, 검사종목은 종양표지자 6종, 갑상선표 지자 5 종 및, 전년도에 이어 올해도 면역단백종목에서 면역글 로불린과 보체 성분 5 종 대신 새로운 표지자들을 도입하였다 〔1,2]. 전년도에 도입한 thyroglobulin과 심장표지자 troponin
는 계속하였고, 전년도에 도입했으나 참가기관이 많지 않은 골 흡수표지자 carboxy-terminal collagen crosslinks (CTX) 대 신 새로운 급성기 바이오표지자 종목인 procalcitonin을 새로 추가하였다. 종목 선정은 외부기관의 자료를 통하여 현재 우 리나라 임상검사실에서 면역측정검사(immunoassay) 방법으 로 가장 활발히 검사가 실시되고 있는 종목들을 선택하였다[38]. 즉 종목 수로 총 13 종의 면역측정법 검사종목을 대상으로 하였다. 대상기관은 지난해까지 본 분과 사업에 참여해 온 기 


\title{
Journal of LABORATORY MEDICINE and QUALITY ASSURANCE
}

\author{
Hyon-Suk Kim et al • EQA of Immunoassay Tests
}

관들과 올해 신규 가입기관, 그리고 새로 참여의사를 밝혀 온 우리 대한임상검사정도관리협회 회원기관들을 대상으로 하였 다[9].

2014년도 신빙도조사사업에 사용한 관리물질은 각 기관당 총 16 개이었는데, 원칙적으로 원가절감을 위하여 주관기관에 서 각 종목별로 검사 후 남은 양성 및 음성 혈청을 수집하여 pooling해서 제조하였다[3-9]. 각 종목별로 임상검사실 결과 치를 살펴보고 높은 결과치를 보이는 검체와 낮은 결과치를 보 이는 검체들을 각각 수집하여 pooling하였다. 이렇게 자가제조 한 관리물질을 각 회당 8 개씩 총 16 개 사용하였으며, 결과치가 높은 검체를 얻기가 어려웠던 갑상선호르몬 종목을 포함하는 관리물질과 새로 시작한 procalcitonin과 심장표지자 troponin 의 고농도 관리물질은 상품화된 제품을 구입하여 사용하였다. 그런데 새로운 종목의 관리물질 비용이 비싸서 1차에는 자가 제조 5 종과 구매한 관리물질 3 종을 사용하였지만, 2 차에는 1 종의 구매한 관리물질과 7개의 자가제조 혈청을 가지고 외부 정도관리를 실시하였다. 즉 2014년 한 해 동안 총 16 종의 관리 물질을 가지고 13 종목에 대해 2 회의 외부정도관리 신빙도조사 를 실시하였다.

\section{재료 및 방법}

\section{1. 관리물질}

외부정도관리 신빙도조사를 위한 관리물질은 2 회의 검체 발 송 시에 각 8 종씩, 총 16 종을 사용하였다. 1 회와 2 회째 모두 갑 상선호르몬검사용 관리물질은 상품화된 제품을 구입하여 사 용하였는데, 높은 결과치를 보이는 혈청을 구하기 어려웠기 때 문이었고, 그 외의 관리물질은 자가제조하는 것을 원칙으로 하 였다. 제조방법은 환자 검사 및 건강검진센터에서 의뢰된 혈청 들을 대상으로 각 종목마다 결과치를 검토하여 각 종목에 따 라 level별로 수집하였다가 pooling하여 제조하였다. 자가제조 한 관리물질과 상품화된 갑상선호르몬 고농도용 물질(MAS Tri-point Liquimmune level 3; Medical Analysis Systems Inc., Camarillo, CA, USA), 그리고 작년부터 새로 추가된 심 장표지자검사용 Elecsys PreciControl Troponin (Roche, Mannheim, Germany)을 구매하여 개별포장하여 냉장택배로 배송하였다. 각 검사종목별로 해당 검체를 사용하여 검사하도 록 각 검체별로 검사종목을 지정하였다.

즉 총 2 회의 외부정도관리 신빙도조사사업에 각 8 종씩의 관 리물질을 우송하였고, 종양표지자, 갑상선호르몬과 올해 새로 실시한 procalcitonin과 심장표지자 종목별로 각 검체를 지정 하여 해당 검사를 실시하도록 하였다. 검체 발송은 1 차는 5 월
13일에, 2차는 11월 11일에 발송하였다.

\section{2. 검사종목}

종양표지자 종목으로 alpha-fetoprotein (AFP), carcinoembryonic antigen (CEA), human chorionic gonadotrophin (HCG, $\beta-\mathrm{HCG}$ ), prostate specific antigen (PSA) 및 carcinoma antigen 125 (CA 125)와 carbohydrate antigen 19-9 (CA 19-9) 등 6종목을 대상으로 하였으며, 갑 상선 기능 검사종목으로 thyroid hormone T3, T4, thyroid stimulating hormone (TSH) 및 free T4 (FT4)외에 작년부 터 새로 thyroglobulin (TG)을 추가하였다. 그리고 전년도에 이어 매년 실시하는 기관 수가 오히려 줄어드는 혈청 면역단백 immunoglobulin G, immunoglobulin A, immunoglobulin $\mathrm{M}$, complement (C)3 및 C4 등 5종 대신 새로 도입된 심장표지자 종목과 procalcitonin에 대하여 외부신빙도조사를 실시하였다.

\section{3. 결과의 분석 및 보고방법}

검사결과의 분석 및 보고방법은 평균, 표준편차, 변이계수 등으로 분석하였으며, 참여기관에서 사용하고 있는 방법과 장 비에 따라 기기별로 분류하여 결과를 분석하였다[3-8]. 전년 도부터 협회에서 전산화를 추진하여 완성되었기에 우리 분과 의 외부신빙도조사 결과 입력은 물론, 전체 방법과 기기별 통 계, 그리고 각 기관의 결과지까지도 인터넷을 이용하여 입력할 수 있었고, 결과지 출력까지도 우리 협회 홈페이지에서 출력할 수 있게 되었다.

$\mathrm{AFP}$ 의 경우 검사결과 보고 단위로 농도 및 국제 단위의 두 가지가 있는데, 현재는 $\mathrm{ng} / \mathrm{mL}$ 의 단위가 더 널리 사용되고 있 는 추세임을 감안하여 2010 년부터는 $\mathrm{ng} / \mathrm{mL}$ 의 단위로 모두 환 산하여 분석하고 있다[1,2]. 각 기관에서 사용하는 검사방법으 로서 reversed passive hemagglutination법 같은 정성이나 반 정량검사를 사용하는 기관들도 아주 적은 수이지만 있었는데, 양성과 음성으로만 결과를 보고하였기 때문에 통계처리대상 에서는 제외하였다.

그리고 갑상선호르몬 검사종목들은 각 기관마다 보고하는 단위와 참고치가 달라서 복잡하였다. 이들 결과치는 통일하여 입력하도록 하였고 그 결과를 통계 처리하였다. 그런데 각 병 원마다 아직도 장비에 따라 보고 단위가 다른 것을 통일하지 않거나 계산결과가 이상한 결과치가 발견되기도 하였다. 그 결 과를 일괄 통계처리하기 전에 이상하다고 생각되는 경우에는 다시 각 기관에 전화를 걸어 확인하였는데, 일일이 해당 기관 에 전화를 해야만 했고 그래도 확인하기 어려운 경우도 있었다. 
Journal of LABORATORY MEDICINE and QUALITY ASSURANCE

Hyon-Suk Kim et al • EQA of Immunoassay Tests

Table 1. 2014 schema of external quality assessment in immunoassay testing

\begin{tabular}{lcccc}
\hline & No. of laboratories invited & Participating laboratories (\%) & Date of procurement of sera & Date of results \\
\hline 1st trial & 712 & $697(97.9 \%)$ & 13 May 2014 & $15 \mathrm{Jul} 2014$ \\
2nd trial & 715 & $700(97.9 \%)$ & 11 Nov 2014 & $26 \mathrm{Dec} 2014$ \\
\hline
\end{tabular}

Table 2. Laboratories participating in the assessment of immunoassay tests in 2014

\begin{tabular}{lcc}
\hline \multirow{2}{*}{ Test marker } & \multicolumn{2}{c}{ Participating laboratories } \\
\cline { 2 - 3 } & 1st trial (\%) & 2nd trial (\%) \\
\hline Tumour markers & $644(92.4)$ & $646(92.3)$ \\
Thyroid markers & $647(92.8)$ & $654(93.4)$ \\
Cardiac markers & & \\
Troponin T & $74(10.6)$ & $75(10.7)$ \\
Troponin I & $254(36.4)$ & $263(37.6)$ \\
New biomarkers & & \\
Procalcitonin & $142(20.4)$ & $160(22.9)$ \\
Results received & $697(100.0)$ & $700(100.0)$ \\
Total no. of institutions invited & 712 & 715 \\
\hline
\end{tabular}

\section{결과}

\section{1. 참여기관}

외부정도관리사업을 위한 검체 발송은 2014년 5월 현재 정 도관리협회에 등록된 기관 중 지난해까지 본 분과사업에 참여 하였거나 또는 이번에 새로 참여의사를 밝힌 기관과 신규 가 입한 기관을 본부 홈페이지에서 내려 받아 대상기관을 파악하 였으며, 1 차에는 712 기관에, 2 차에는 715 기관에 검체를 발송 하였다. 2014년도에 외부정도관리사업 결과, 회신기관 수는 1 차 697기관, 2차 700기관이었다(Table 1). 전체 참여기관 수 는 2005년도 2차 305 기관에 비하여 현재 2014년에는 2배 이 상 참여기관이 많이 증가하였다.

참여한 기관들에 대해서 각각의 검사종목별로 살펴보면 종 양표지자 종목에는 1차와 2 차에 각각 644 기관과 646 기관, 갑 상선호르몬 종목에는 647 기관과 654기관, 그리고 새로운 종목 에는 종목에 따라서 troponin-I (TnI)/troponin-T (TnT)는 1 차와 2 차 각각 $254 / 74$ 기관, $263 / 75$ 기관에서 검사결과를 회신 하였다(Table 2). 또 procalcitonin의 경우 1차 142기관, 2 차 160 기관에서 회신하였다.

\section{2. 검사종목별 회신율}

면역측정검사 정도관리 검사종목별 회신기관 수는 Table 3 에 표시하였다. 전년도에 비하여 대상기관 수와 회신기관 수는
Table 3. Current status of individual test markers used in the immunoassay test in clinical laboratories in 2014

\begin{tabular}{|c|c|c|}
\hline \multirow{2}{*}{ Test marker } & \multicolumn{2}{|c|}{ Participating laboratories } \\
\hline & 1st trial & 2nd trial \\
\hline \multicolumn{3}{|l|}{ Tumour markers } \\
\hline Alpha-fetoprotein & 644 & 646 \\
\hline Carcinoembryonic antigen & 552 & 554 \\
\hline Carcinoma antigen 125 & 432 & 436 \\
\hline Carbohydrate antigen 19-9 & 473 & 478 \\
\hline Prostate specific antigen & 532 & 538 \\
\hline HCG & 156 & 153 \\
\hline$\beta$-HCG & 4 & 6 \\
\hline \multicolumn{3}{|l|}{ Thyroid markers } \\
\hline T3 & 562 & 566 \\
\hline $\mathrm{T} 4$ & 146 & 135 \\
\hline Free T4 & 629 & 635 \\
\hline Thyroid stimulating hormone & 647 & 654 \\
\hline Thyroglobulin & 70 & 71 \\
\hline \multicolumn{3}{|l|}{ Cardiac markers } \\
\hline Troponin $\mathrm{T}$ & 74 & 75 \\
\hline Troponin I & 254 & 263 \\
\hline \multicolumn{3}{|l|}{ New biomarkers } \\
\hline Procalcitonin & 142 & 160 \\
\hline Results received & 697 & 700 \\
\hline Total no. of institutions invited & 712 & 715 \\
\hline
\end{tabular}

Abbreviations: HCG, human chorionic gonadotrophin; T, thyroid hormone.

꾸준히 늘어나고 있음을 알 수 있다. 특히 10년간 별로 실시하 는 기관이 늘지 않은 혈청면역단백 종목들 대신에 새로운 표 지자를 시도하였는데 전년도에 이어 심장표지자검사는 참여 기관의 $47 \%$ 이상에서 실시하고 있으며, 동일 기종을 사용하 는 기관들 간에는 편차가 크지 않았다. 그러나 다른 종류의 장 비 간에는 다른 종목과 마찬가지로 면역자동분석기의 특성대 로 결과치에 차이가 있음을 알 수 있었다. 2014년도 외부정도 관리에 사용한 관리물질을 Table 4에 정리하였다. 
Table 4. Control materials used for the immunoassay external quality assessment in 2014

\begin{tabular}{|c|c|c|c|}
\hline Test marker & Test item & 1st trial & 2nd trial \\
\hline \multirow[t]{7}{*}{ Tumour markers } & Alpha-fetoprotein & Specimen no. 1, 2 (14-IA-1, 2) & Specimen no. 9, 10 (14-IA-9, 10) \\
\hline & Carcinoembryonic antigen & & \\
\hline & Carcinoma antigen 125 & & \\
\hline & Carbohydrate antigen 19-9 & & \\
\hline & HCG & & \\
\hline & $\beta-\mathrm{HCG}$ & & \\
\hline & PSA & Specimen no. $3^{*}, 4\left(14-\mathrm{IA}-3^{*}, 4\right)$ & Specimen no. $11^{\star}, 12\left(14-\mathrm{IA}-11^{\star}, 12\right)$ \\
\hline \multirow[t]{5}{*}{ Thyroid markers } & T3 & & \\
\hline & $\mathrm{T} 4$ & & \\
\hline & Free T4 & & \\
\hline & Thyroid stimulating hormone & & \\
\hline & Thyroglobulin & & \\
\hline \multirow[t]{2}{*}{ Cardiac markers } & Troponin T & Specimen no. $7^{\star}, 8^{\star}\left(14-\mathrm{IA}-7^{\star}, 8^{\star}\right)$ & Specimen no. 15, $16(14-\mathrm{IA}-15,16)$ \\
\hline & Troponin I & & \\
\hline New biomarker & Procalcitonin & Specimen no. 5, 6 (14-IA-5, 6) & Specimen no. $13,14(14-\mathrm{IA}-13,14)$ \\
\hline
\end{tabular}

Abbreviations: HCG, human chorionic gonadotrophin; T, thyroid hormone.

${ }^{*}$ Commercial sera: others were pooled sera prepared by the Immunoassay Subcommittee.

\section{3. 면역측정검사 검사방법 및 장비의 사용 현황}

2014년도 면역측정검사 정도관리사업에 참여한 기관들의 각 검사종목을 검사방법 및 기기별로 구분하여 Tables 5-19 에 정리하였다. Enzyme immunoassay 장비들에서 chemiluminiscence immunoassay 장비들로 거의 전환되어 현 재 참여하고 있는 임상검사실들에서 주로 사용되고 있는 것은 chemiluminiscence immunoassay를 이용하는 장비들이었다.

\section{4. 정도관리물질}

올해 정도관리에 사용한 상품화된 정도관리물질(MAS Tripoint Liquimmune level 3; Medical Analysis Systems Inc.) 은 갑상선호르몬검사에 사용하도록 지정하였고, 나머지 다른 관리물질은 환자와 건강인의 pooled sera를 level별로 모아 냉 동보관하였다가 자가제조한 것이었다. 각 검사종목별로 환자 들의 검사결과를 확인하고 혈청을 pooling하여 각 level을 제 조하였다. 단, 높은 농도의 검체를 대량 구하기 어려운 갑상선 호르몬 종목과 새로운 표지자로 선정한 심장표지자검사용은 상품화된 물질을 구입하여 제조하였다. 일부 level 검체들은 정상인의 혈청을 가지고 희석하여 제조하였다.

\section{5. 분과 워크샵}

2014년에는 협회 전체 통합워크숍이 있었는데 우리 분과에 서도 참여하였으며, 또 추계학술대회에서도 우리 면역측정검
사분과에서 필요한 내용을 선택하여 참여하였다.

\section{고찰}

최근에 면역측정검사와 관련된 분야에서는 검사방법이 민감 도와 특이도가 높은 화학발광법과 이에 따른 여러 가지 유사한 검사방법들인 electrochemiluminescence immunoassay 등 의 방법들이 도입되었다. 즉 면역측정검사 중 많은 종류의 검 사가 기존의 RIA방법에서부터 enzyme immunoassay로, 다 시 chemiluminescence immunoassay로 빠르게 대치되었다 〔10]. 이는 면역측정검사에 도입되는 면역효소법 및 화학발광 법이 이제는 방사성 동위원소검사법보다 더 높은 민감도와 특 이도를 가지게 되었으며 유효기간이 더 길다는 등 장점이 많고 자동화가 가능하여 현대 임상검사실의 요구도와 잘 맞아 떨어 지고 있기 때문으로 생각된다.

종양표지자 검사종목들은 원래 스크리닝 목적으로 사용하 는 것이 권장되지 않지만 우리나라에서는 흔히 건강검진 등에 포함되기 때문에 검사를 실시하는 기관 수가 많은 것으로 생각 되었는데, 특히 남성 종양표지자로 흔히 사용되는 PSA와 여 성 종양표지자로 볼 수 있는 CA 125 등을 실시하는 기관들을 살펴보면, 이 종목들이 검진목적으로 사용되고 있는 것으로 생 각되었다. 참고로 이때 다른 여성 종양표지자라고 할 수 있는 $\mathrm{HCG}$ 나 $\beta-\mathrm{HCG}$ 를 실시하는 기관은 비교적 많지 않았다. 특히 


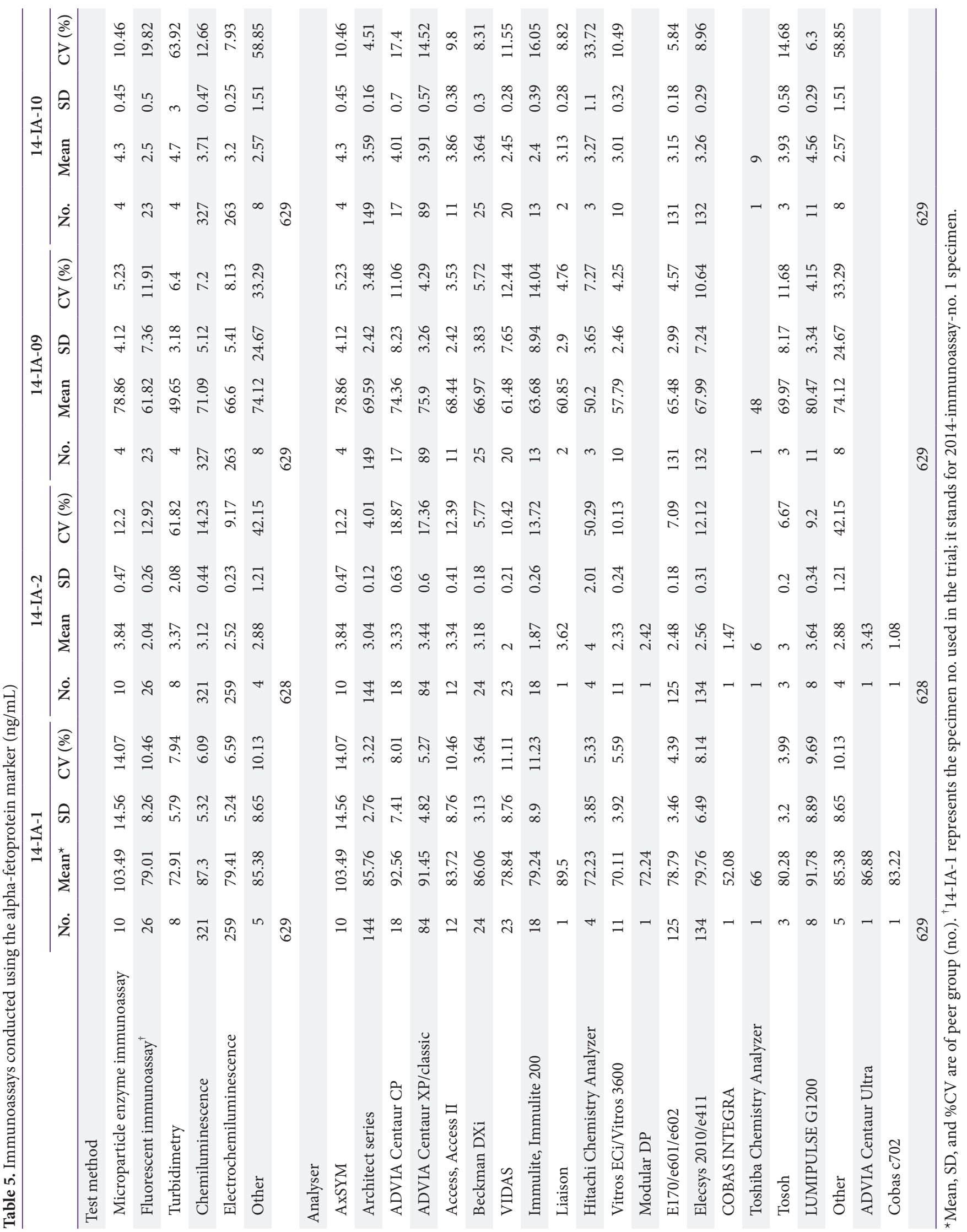




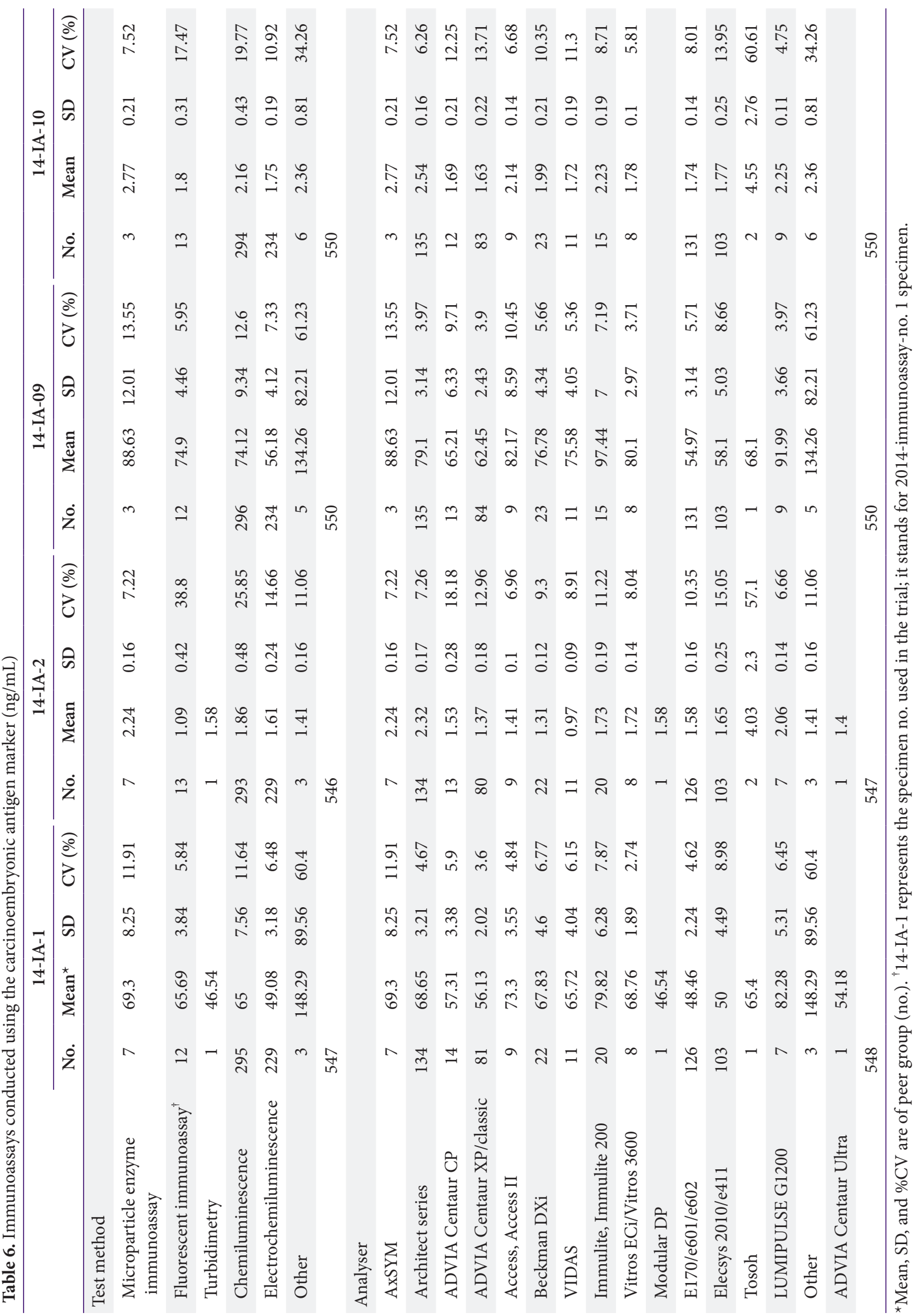




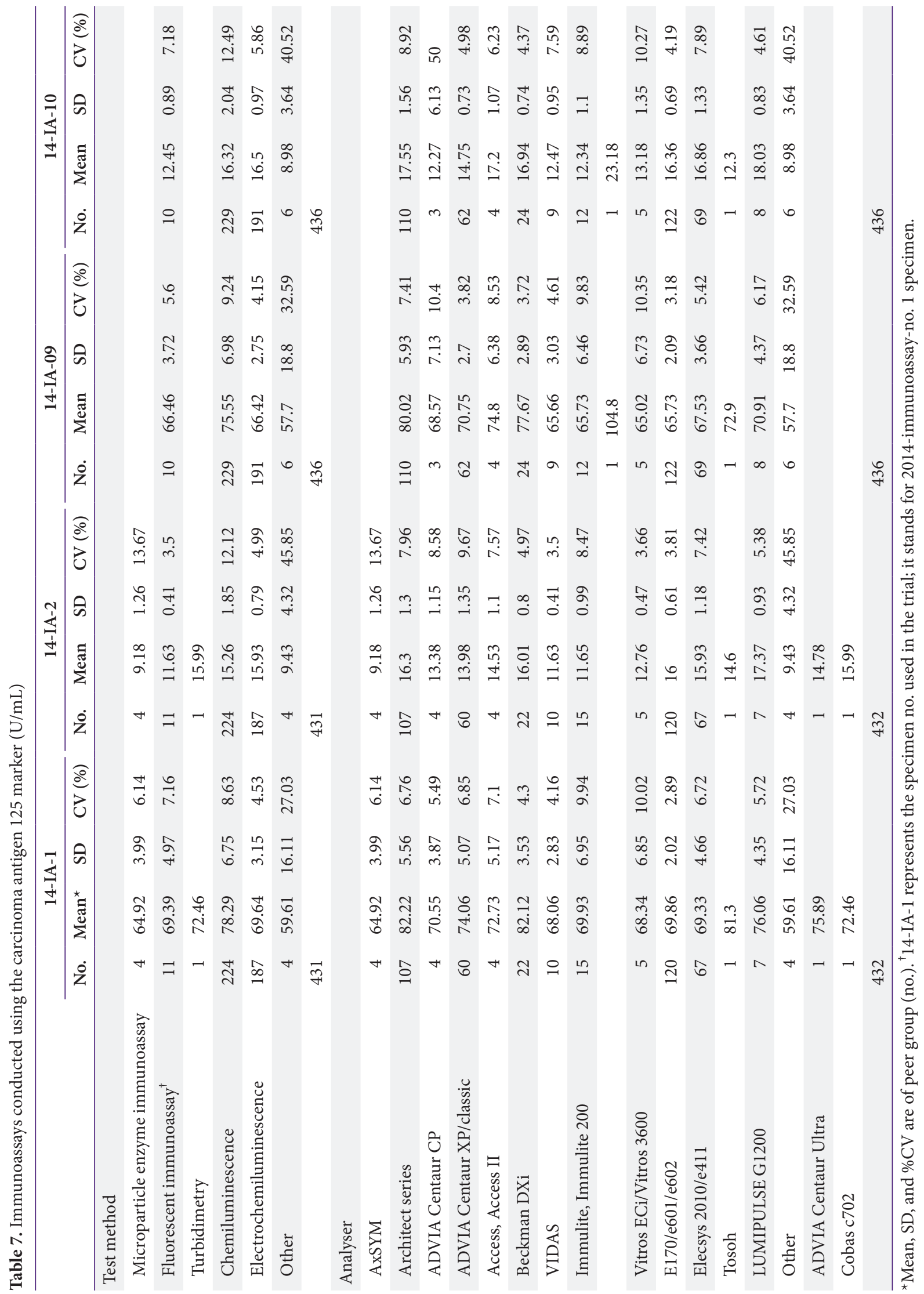




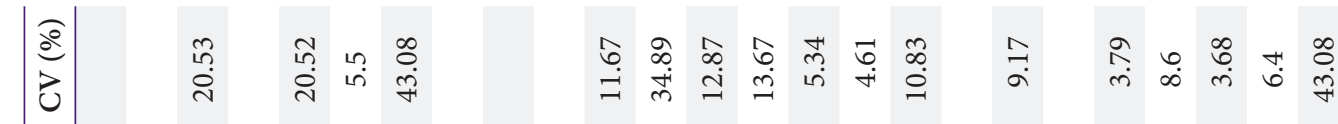

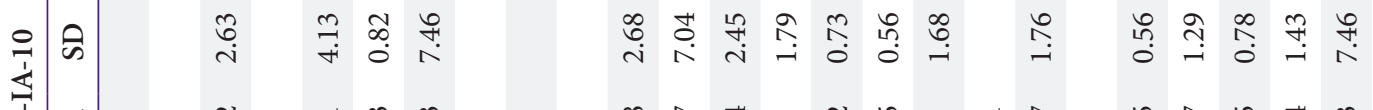

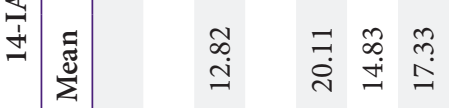

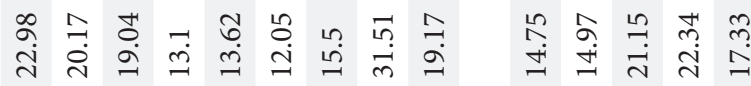

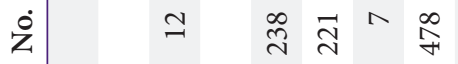

ᄋิ

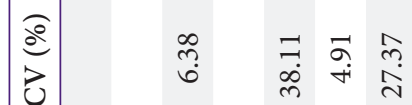

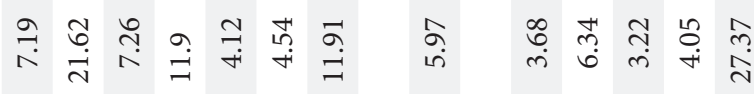

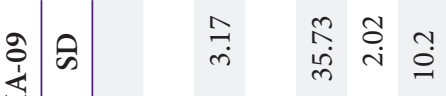

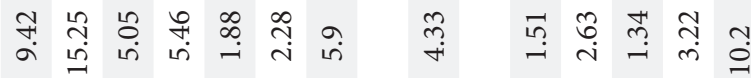

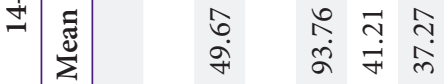

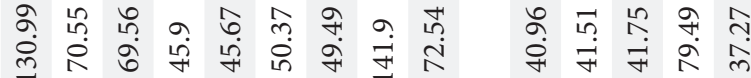

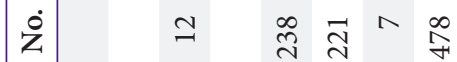

ᄋ

mi $\infty a n$

a

Fे

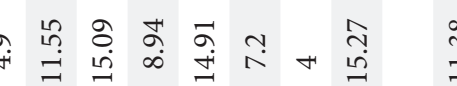

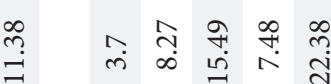

ก

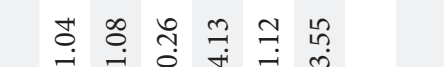

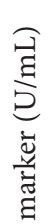

亲

ఫ艹

à

के

ఝ

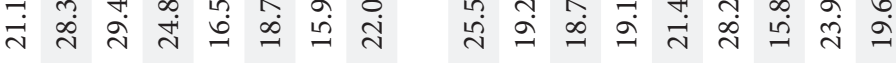

n $m \underset{4}{4} \underset{4}{\pi}$

n $\hat{0})^{\infty}$ in $\mathcal{N}=$

$n-$ ลे

$\operatorname{cr} \rightarrow-\stackrel{f}{\infty}$

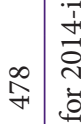

$\frac{a}{3}$



\#

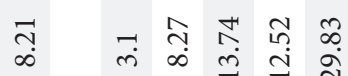

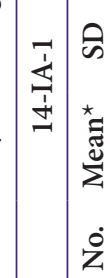

क ते छ

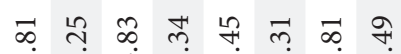

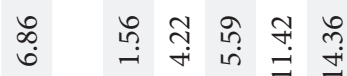

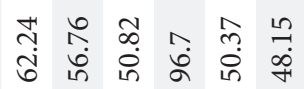

से तิ

तु

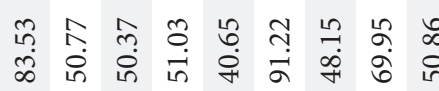

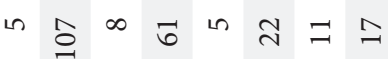

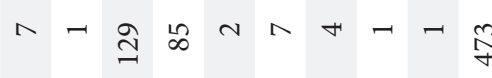

n $\sqrt{\stackrel{4}{4}} \underset{4}{\stackrel{4}{4}}$
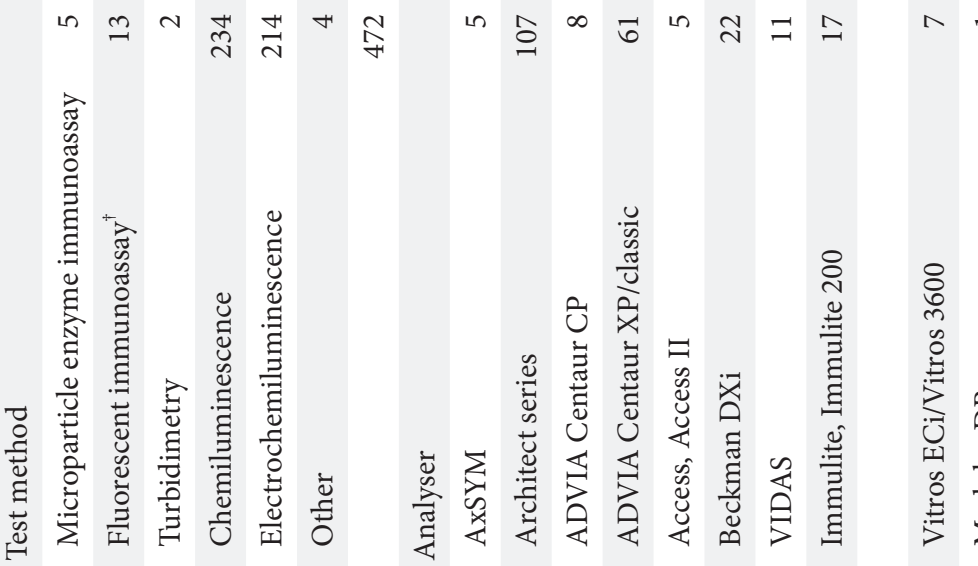

年

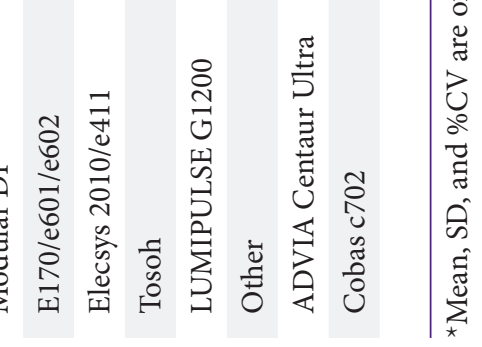




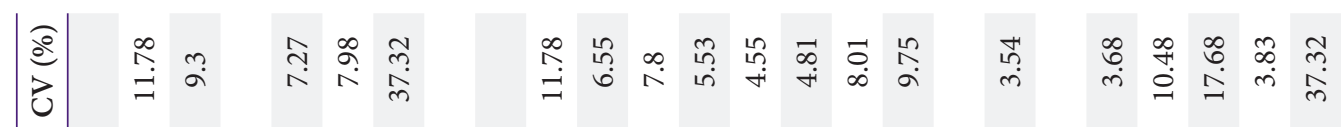

产

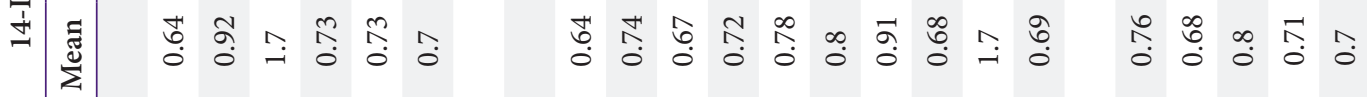

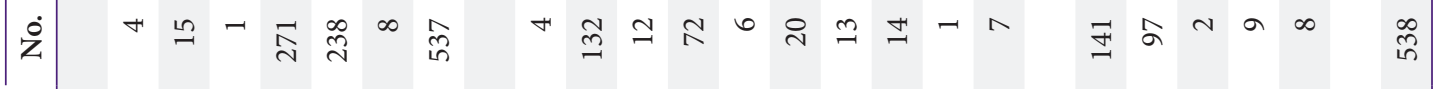

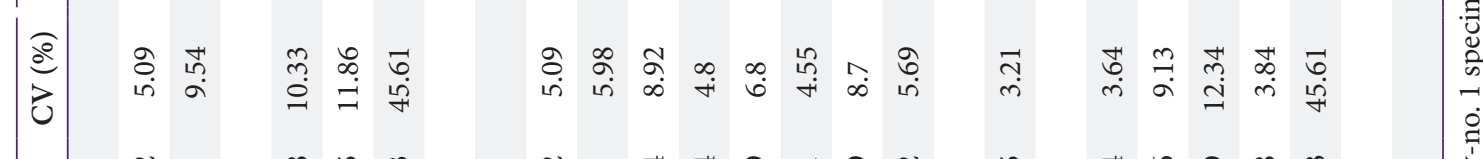

के

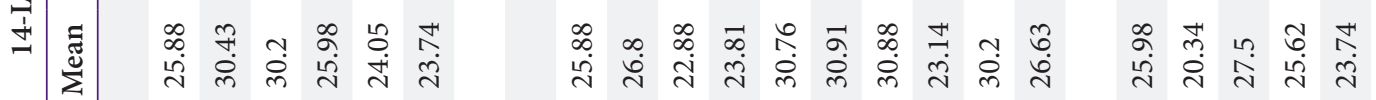

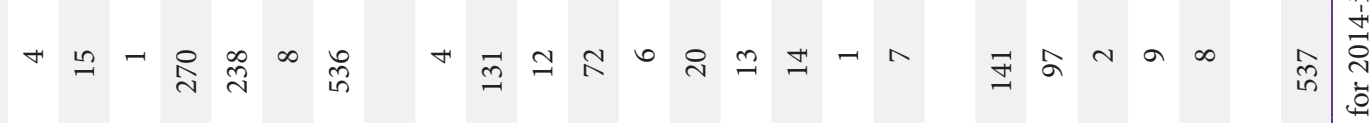

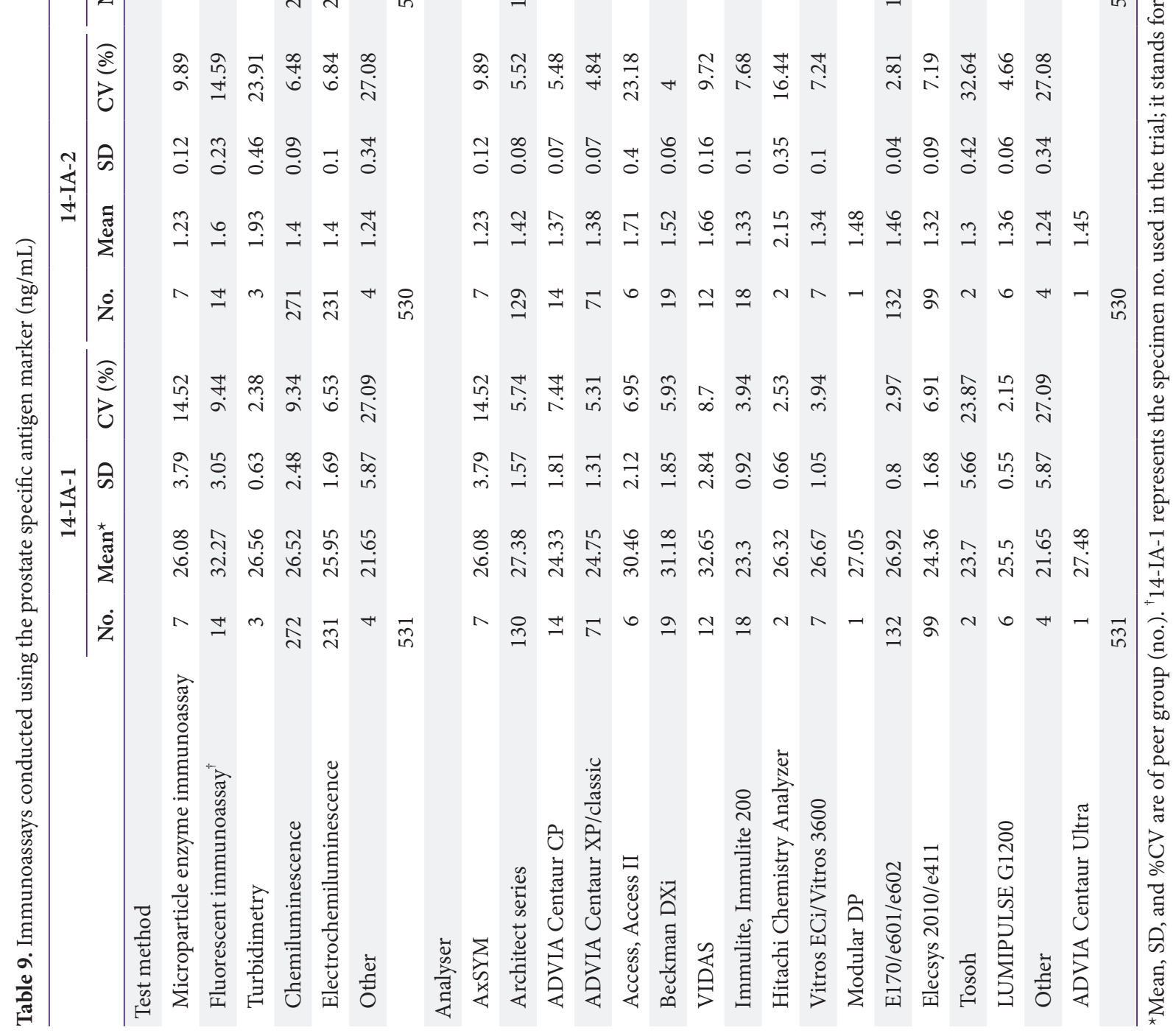


Journal of LABORATORY MEDICINE and QUALITY ASSURANCE

Hyon-Suk Kim et al • EQA of Immunoassay Tests

Table 10. Immunoassays conducted using the human chorionic gonadotrophin marker (IU/L)

\begin{tabular}{|c|c|c|c|c|c|c|c|c|c|c|c|c|c|c|c|c|}
\hline & \multicolumn{4}{|c|}{ 14-IA-1 } & \multicolumn{4}{|c|}{ 14-IA-2 } & \multicolumn{4}{|c|}{ 14-IA-09 } & \multicolumn{4}{|c|}{14 -IA-10 } \\
\hline & No. & Mean* & SD & $\begin{array}{l}\mathrm{CV} \\
(\%)\end{array}$ & No. & Mean & SD & $\begin{array}{l}\mathrm{CV} \\
(\%)\end{array}$ & No. & Mean & SD & $\begin{array}{l}\mathrm{CV} \\
(\%)\end{array}$ & No. & Mean & SD & $\begin{array}{l}\mathrm{CV} \\
(\%)\end{array}$ \\
\hline \multicolumn{17}{|l|}{ Test method } \\
\hline $\begin{array}{l}\text { Fluorescent } \\
\text { immunoassay }^{\dagger}\end{array}$ & 5 & 103.61 & 11.33 & 10.93 & 5 & 14.96 & 2.34 & 15.62 & 4 & 144.97 & 7.07 & 4.88 & 4 & 22.71 & 2.95 & 13 \\
\hline $\begin{array}{l}\text { Chemilumi- } \\
\text { nescence }\end{array}$ & 95 & 99.09 & 6.64 & 6.7 & 95 & 15.8 & 0.98 & 6.22 & 92 & 136.17 & 10.51 & 7.72 & 92 & 21.08 & 1.6 & 7.58 \\
\hline \multirow{2}{*}{$\begin{array}{l}\text { Electrochemilu- } \\
\text { minescence }\end{array}$} & 55 & 87.07 & 4.32 & 4.96 & 55 & 13.63 & 0.78 & 5.72 & 56 & 120.18 & 4.84 & 4.03 & 56 & 18.47 & 0.91 & 4.91 \\
\hline & 155 & & & & 155 & & & & 152 & & & & 152 & & & \\
\hline \multicolumn{17}{|l|}{ Analyser } \\
\hline \multirow[t]{2}{*}{ Architect series } & 49 & 97.93 & 4.91 & 5.01 & 49 & 15.7 & 0.98 & 6.24 & 44 & 134.95 & 6.8 & 5.04 & 44 & 20.72 & 1.14 & 5.49 \\
\hline & & & & & & & & & 1 & 151.6 & & & 1 & 21.2 & & \\
\hline $\begin{array}{l}\text { ADVIA Centaur } \\
\text { XP/classic }\end{array}$ & 23 & 107.55 & 5.13 & 4.77 & 23 & 16.01 & 1.03 & 6.42 & 24 & 145.86 & 6.63 & 4.55 & 24 & 22.06 & 1.48 & 6.73 \\
\hline Access, Access II & 4 & 89.05 & 2.29 & 2.57 & 4 & 15.13 & 0.32 & 2.12 & 6 & 122.78 & 8.51 & 6.93 & 6 & 19.97 & 2.33 & 11.65 \\
\hline Beckman DXi & 15 & 93.37 & 4.68 & 5.01 & 15 & 15.86 & 1.36 & 8.58 & 13 & 122.69 & 6.98 & 5.69 & 13 & 20.09 & 1.62 & 8.08 \\
\hline VIDAS & 5 & 103.61 & 11.33 & 10.93 & 5 & 14.96 & 2.34 & 15.62 & 4 & 144.97 & 7.07 & 4.88 & 4 & 22.71 & 2.95 & 13 \\
\hline $\begin{array}{l}\text { Immulite, } \\
\text { Immulite } 200\end{array}$ & 4 & 100.6 & 3.13 & 3.11 & 4 & 16.25 & 0.71 & 4.39 & 4 & 142.93 & 10.83 & 7.58 & 4 & 23.23 & 1.92 & 8.26 \\
\hline E170/e601/e602 & 43 & 88.63 & 2.63 & 2.97 & 43 & 13.89 & 0.5 & 3.56 & 46 & 121.06 & 3.56 & 2.94 & 46 & 18.66 & 0.71 & 3.78 \\
\hline \multirow{2}{*}{$\begin{array}{l}\text { Elecsys 2010/ } \\
\text { e411 }\end{array}$} & 12 & 81.65 & 5.62 & 6.88 & 12 & 12.57 & 1.23 & 9.77 & 10 & 113.99 & 10.5 & 9.21 & 10 & 17.33 & 2.09 & 12.08 \\
\hline & 155 & & & & 155 & & & & 152 & & & & 152 & & & \\
\hline
\end{tabular}

${ }^{*}$ Mean, SD, and \%CV are of peer group (no.). ${ }^{\dagger} 14$-IA-1 represents the specimen no. used in the trial; it stands for 2014-immunoassay-no. 1 specimen.

Table 11. Immunoassays conducted using the $\beta$-human chorionic gonadotrophin marker $(\mathrm{ng} / \mathrm{mL})$

\begin{tabular}{|c|c|c|c|c|c|c|c|c|c|c|c|c|c|c|c|c|}
\hline & \multicolumn{4}{|c|}{ 14-IA-1 } & \multicolumn{4}{|c|}{ 14-IA-2 } & \multicolumn{4}{|c|}{ 14-IA-09 } & \multicolumn{4}{|c|}{ 14-IA-10 } \\
\hline & No. & Mean $^{*}$ & SD & $\begin{array}{l}\text { CV } \\
(\%)\end{array}$ & No. & Mean & $\mathrm{SD}$ & $\begin{array}{l}\text { CV } \\
(\%)\end{array}$ & No. & Mean & SD & $\begin{array}{l}\text { CV } \\
(\%)\end{array}$ & No. & Mean & $\mathrm{SD}$ & $\begin{array}{l}\mathrm{CV} \\
(\%)\end{array}$ \\
\hline \multicolumn{17}{|l|}{ Test method } \\
\hline $\begin{array}{l}\text { Fluorescent } \\
\text { immunoassay }^{\dagger}\end{array}$ & 3 & 93.58 & 2.8 & 2.99 & 3 & 14.77 & 1.98 & 13.43 & 5 & 145.46 & 12.36 & 8.49 & 5 & 20.04 & 1.53 & 7.63 \\
\hline \multirow[t]{2}{*}{ Chemiluminescence } & 1 & 74.7 & & & 1 & 11.9 & & & 1 & 97.5 & & & 1 & 15.4 & & \\
\hline & 4 & & & & 4 & & & & 6 & & & & 6 & & & \\
\hline \multicolumn{17}{|l|}{ Analyser } \\
\hline VIDAS & 3 & 93.58 & 2.8 & 2.99 & 3 & 14.77 & 1.98 & 13.43 & 5 & 145.46 & 12.36 & 8.49 & 5 & 20.04 & 1.53 & 7.63 \\
\hline \multirow[t]{2}{*}{ VISTA } & 1 & 74.7 & & & 1 & 11.9 & & & 1 & 97.5 & & & 1 & 15.4 & & \\
\hline & 4 & & & & 4 & & & & 6 & & & & 6 & & & \\
\hline
\end{tabular}

${ }^{*}$ Mean, SD, and \%CV are of peer group (no.). ${ }^{\dagger} 14$-IA-1 represents the specimen no. used in the trial; it stands for 2014-immunoassay-no. 1 specimen. 


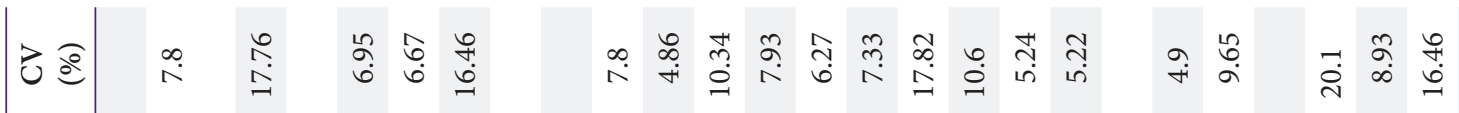

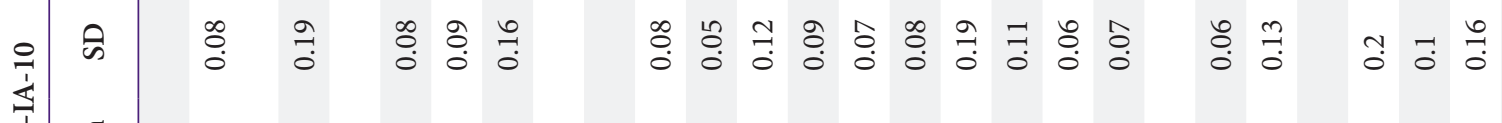

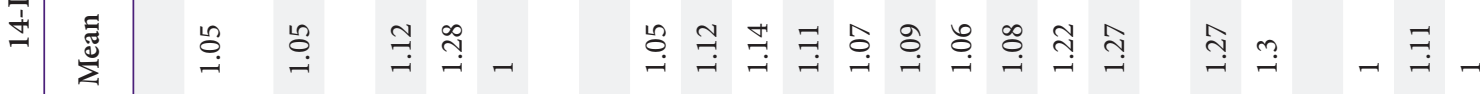

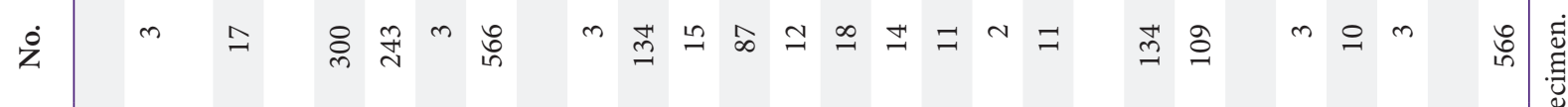

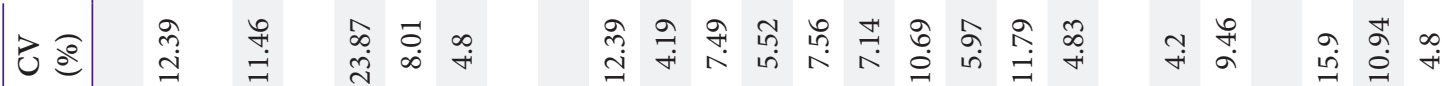

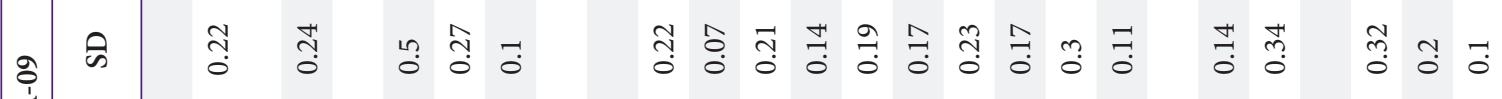

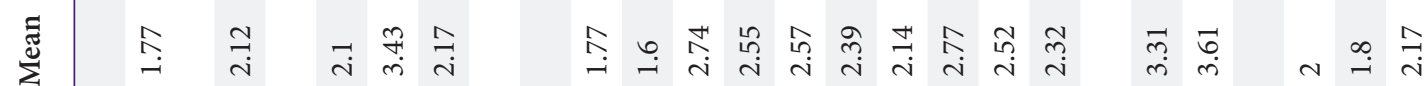

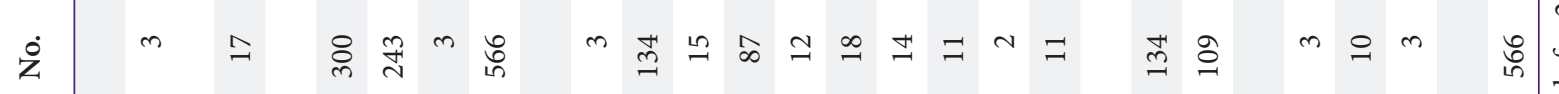

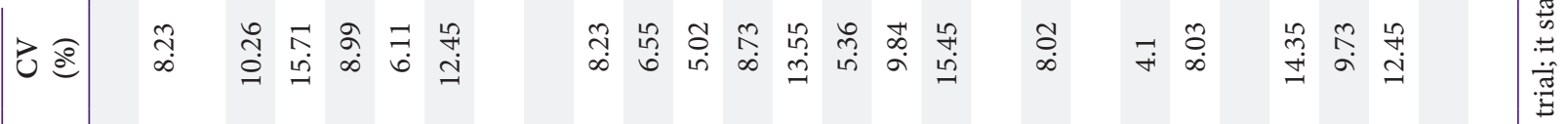

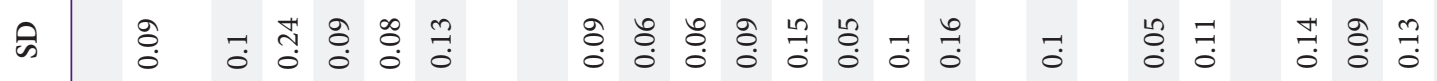

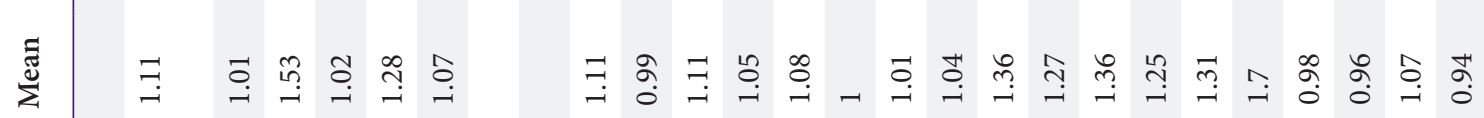

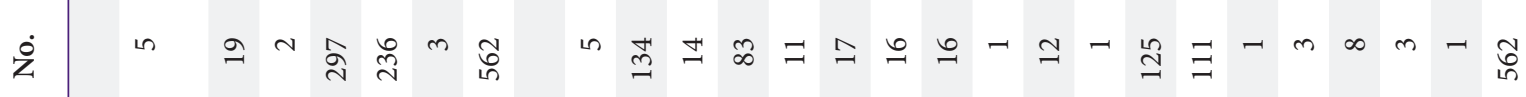

ப)

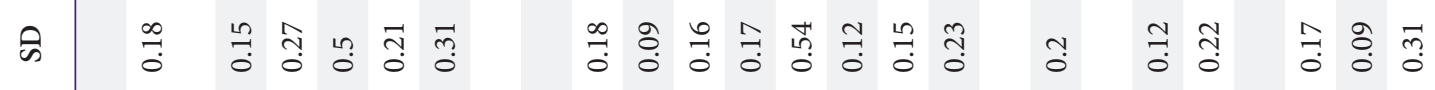

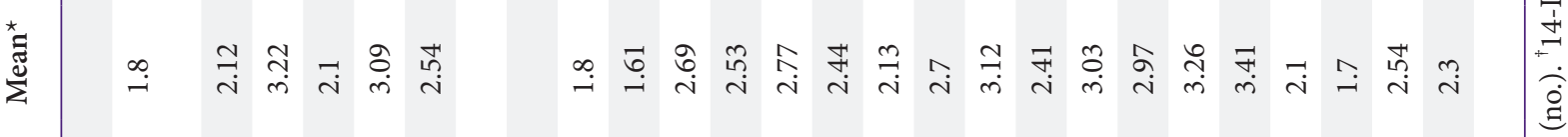

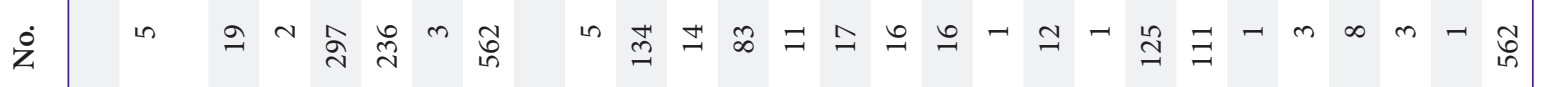

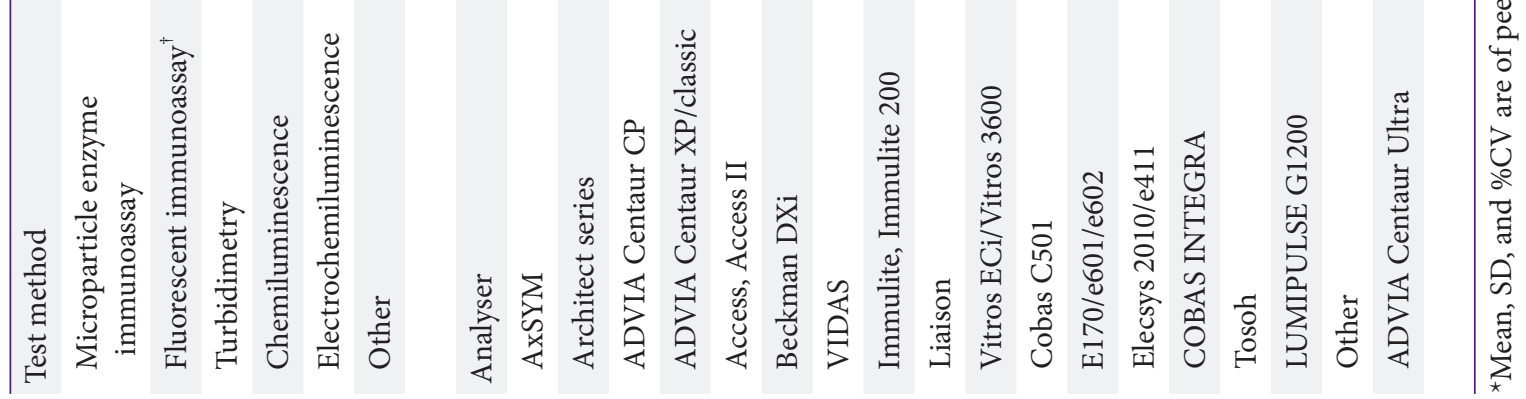




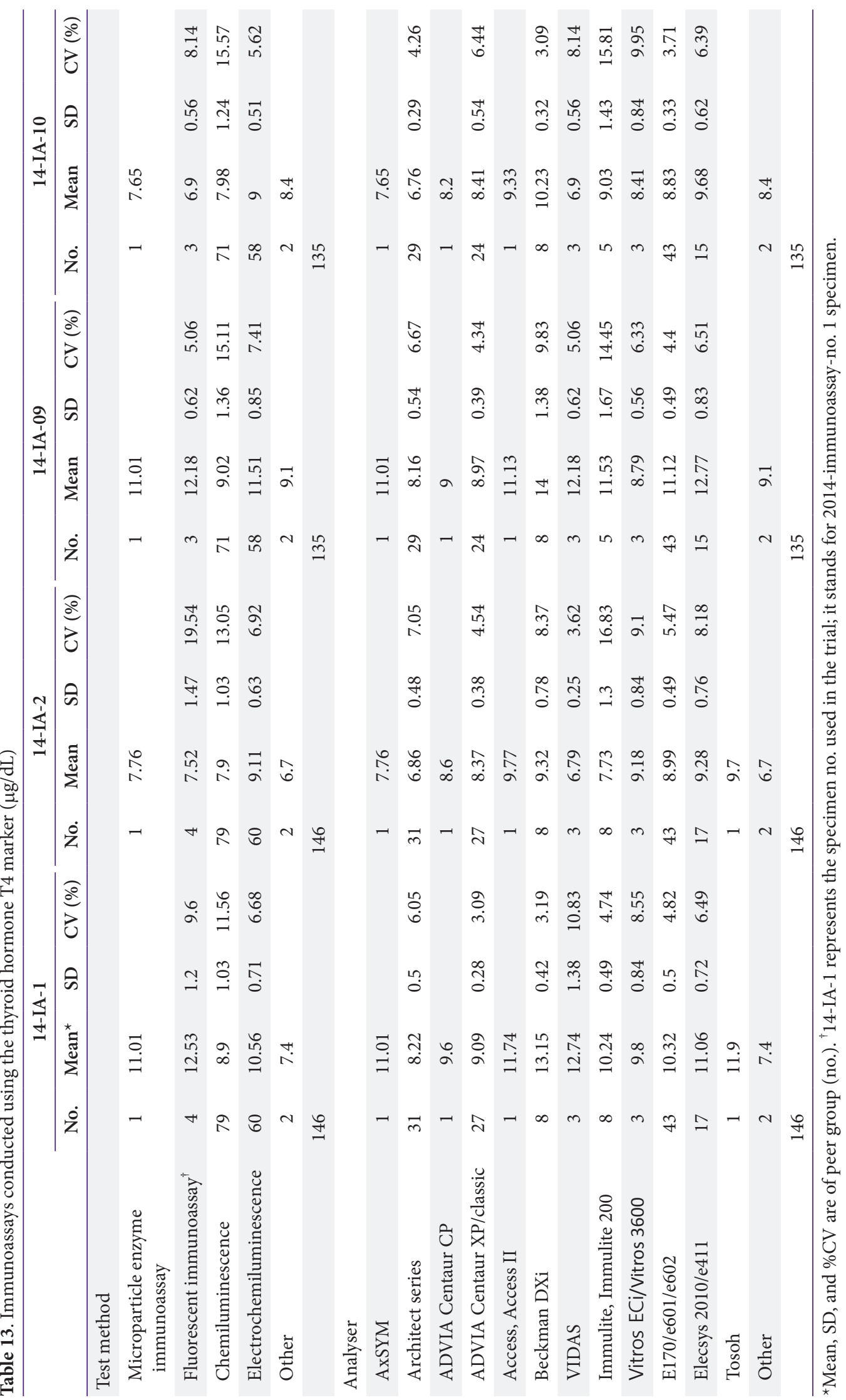




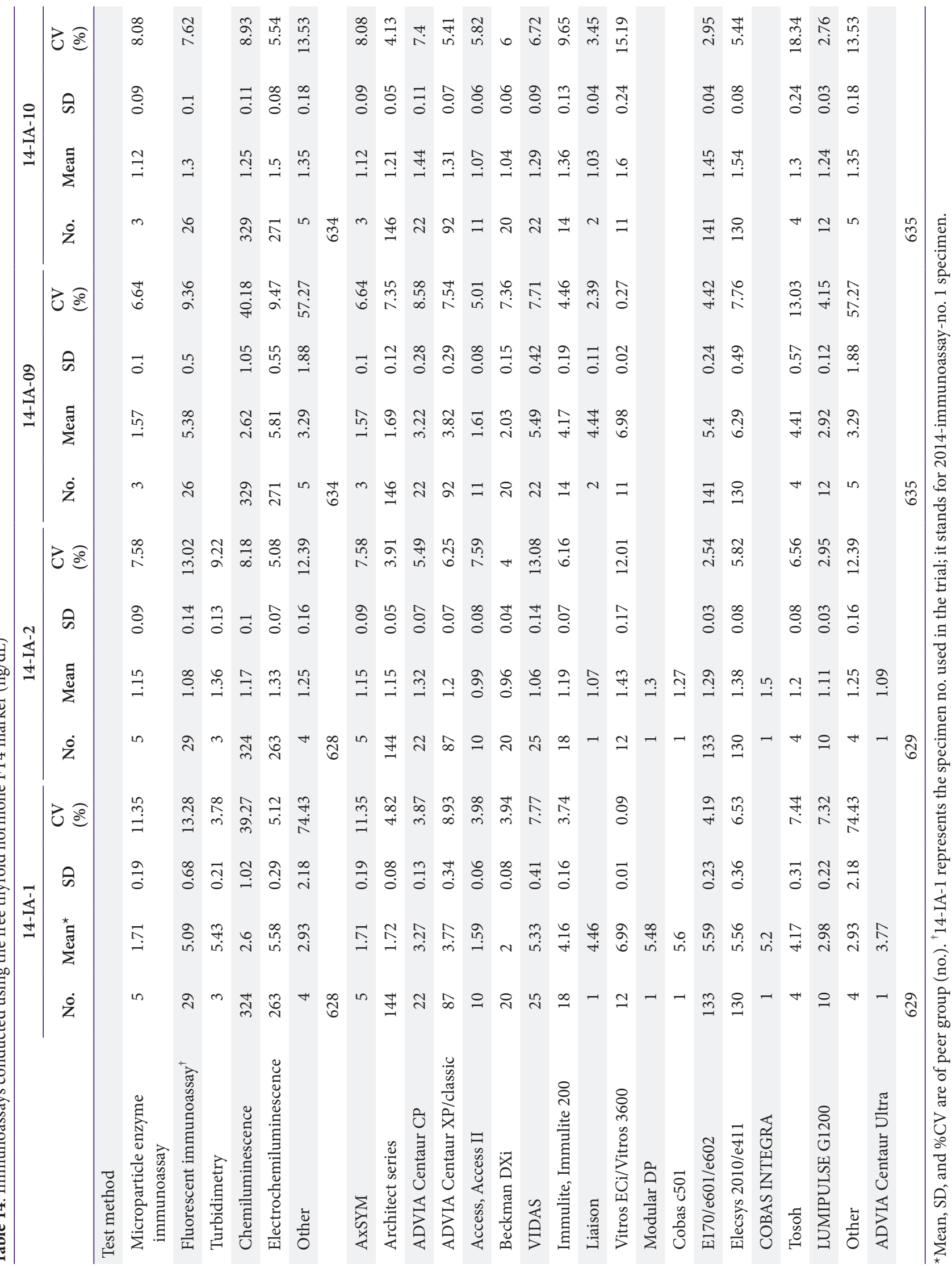




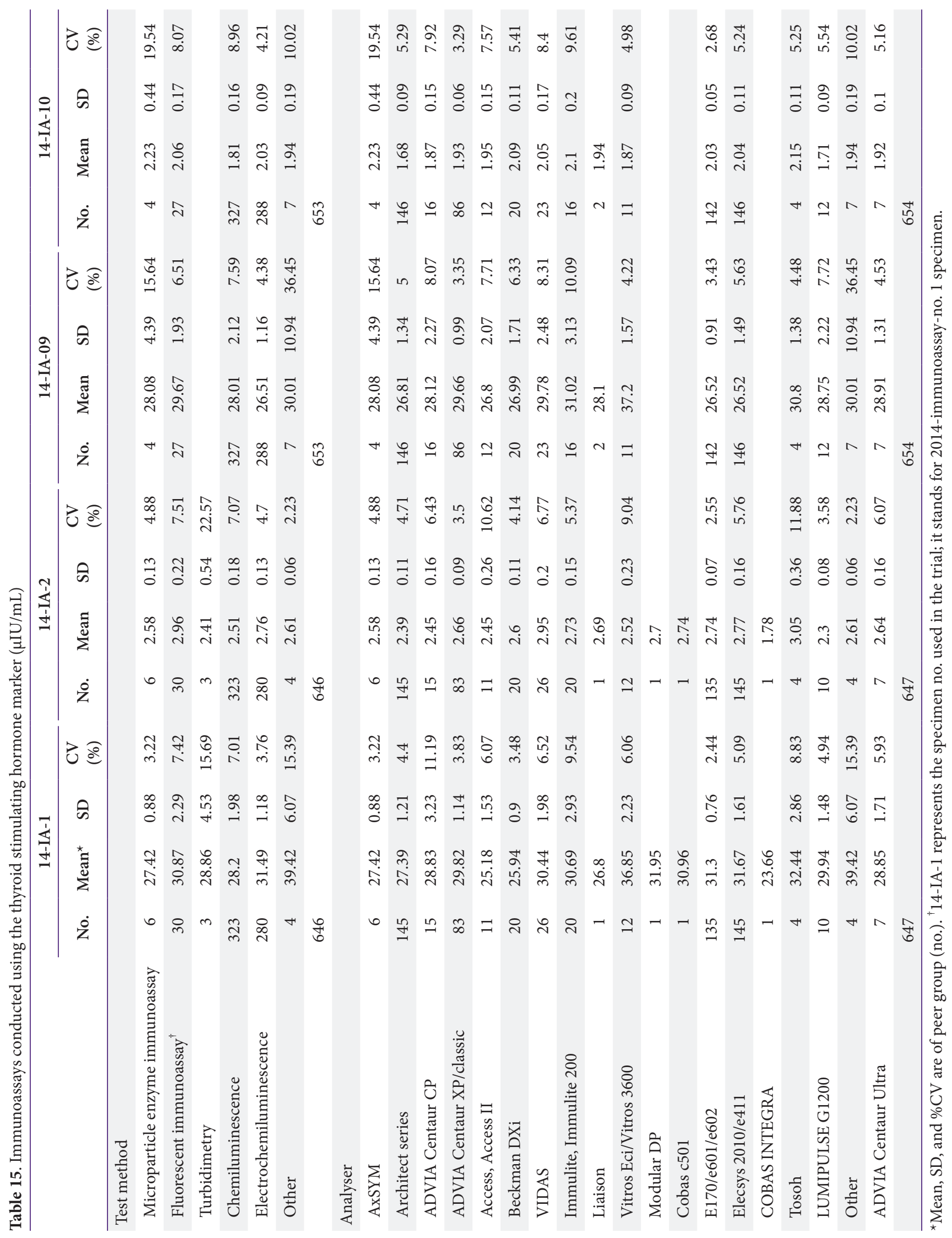




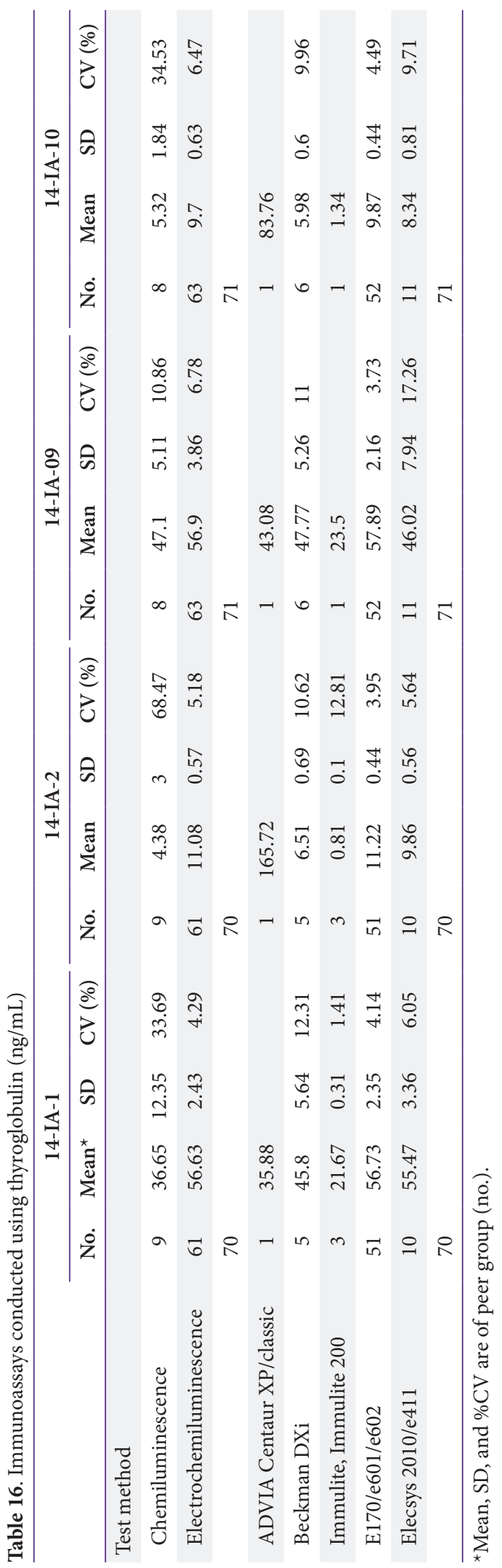

장비에 따라 $\beta-\mathrm{HCG}$ 가 아니라 $\mathrm{HCG}$ 로 측정하는 기관 수가 현 저히 많아진 것으로 생각된다. 그리고 각 종양표지자 종목들 의 통계 분석결과가 서로 다른 종양표지자 종목들이라도 비슷 하였는데, 그 이유는 각 기관에서 어떤 장비든지 동일한 자동 면역분석기를 이용하여 종양표지자검사들을 실시하기 때문에 장비의 특성에 따라 비슷하게 나타난 것으로 생각되었다.

전년도에 이어 2014년도에도 과거 10여 년간 혈청면역단 백을 하던 것을 외부정도관리사업의 문제점을 보완하고자 새 로 도입된 종목들을 시도하였다[11-15]. 참여도가 높지 않은 CTX 대신 procalcitonin 등 새로운 염증 및 항균제 모니터링 검사 등을 시도하여 보았다. Procalcitonin의 경우 심장표지자 보다는 많이 실시하지 않고 있었지만, 골흡수표지자보다는 훨 씬 많은 160 기관에서 결과를 회신하였다.

아직도 각 기관에서 결과입력을 마친 후 그 입력된 전체결과 를 다시 검토하거나 확인하지 않기 때문에 생기는 것으로 생각 되는 사무 오류들이 제일 많았다[16]. 단위까지 확인하는 정확 한 결과 입력 등 좀더 세심하게 사무적 착오에 대해 확인할 필 요가 있을 것으로 생각된다. 따라서 아직도 결과분석 전에는 본 분과 담당자들이 일일이 전화를 하여 확인할 필요가 있다는 것이 문제점으로 파악된다 $[17,18]$. 각 회원기관들에서 외부정 도관리물질로 검사를 실시하고 나서 그 결과를 인터넷에 입력 또는 회신하기 전에 각 담당자 또는 책임자들이 재검토하고 정 확히 확인하여 각 기관의 결과를 입력/회신하여 준다면 크게 도움이 될 것이다[19-21]. 그리고 자신이 입력한 결과를 다시 한번 꼼꼼이 확인하여 준다면 사무적 오차를 대폭 줄인 정확한 확인이 가능할 것으로 생각된다.

2008년부터는 전체 병원의 통계는 우리 협회 홈페이지에서 내려받거나 출력할 수 있게 되었으며, 따라서 보고서 송부 시 에 두꺼운 전체 기관 통계자료를 같이 보내지 않게 되었고 각 기관에서도 필요할 때마다 인터넷에서 확인할 수 있었다. 뿐만 아니라 2010년부터는 각 기관의 결과지까지도 수시로 협회 인 터넷 홈페이지에서 출력할 수 있도록 협회차원에서 전산화가 구축되었기에 각 참여기관들도 훨씬 편리하고 수시로 확인해 볼 수 있었다.

\section{감사의 글}

본 면역측정검사분과 외부정도관리사업을 위해서 자가제조 용 관리물질 검체를 농도별로 수집하고 우송, 안정성 검사과정 에서 헌신적으로 도와주신 연세의료원 진단검사의학과 교직 원 여러분과 우리 협회 면역측정검사 분과위원들께 깊이 감사 드린다. 


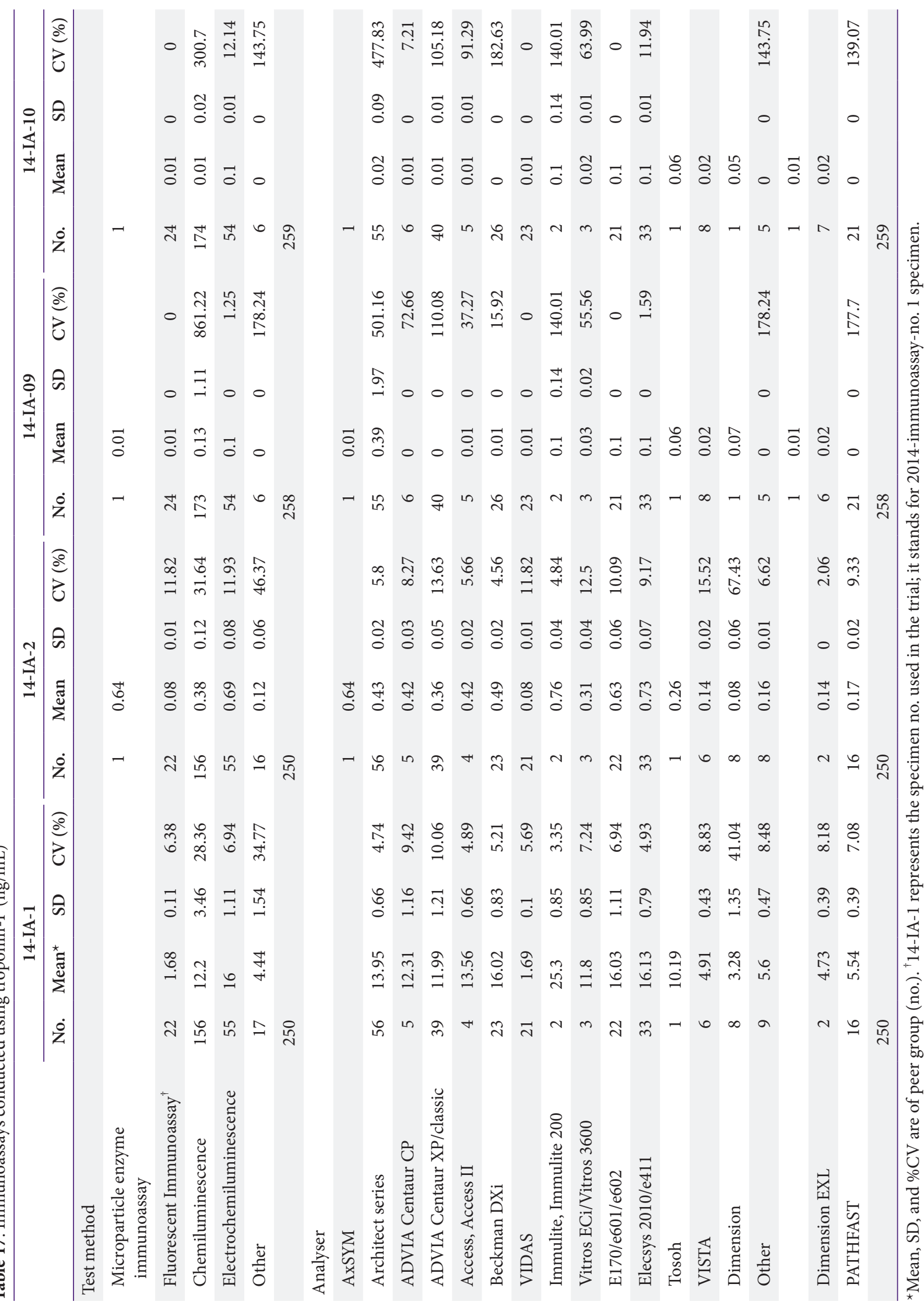




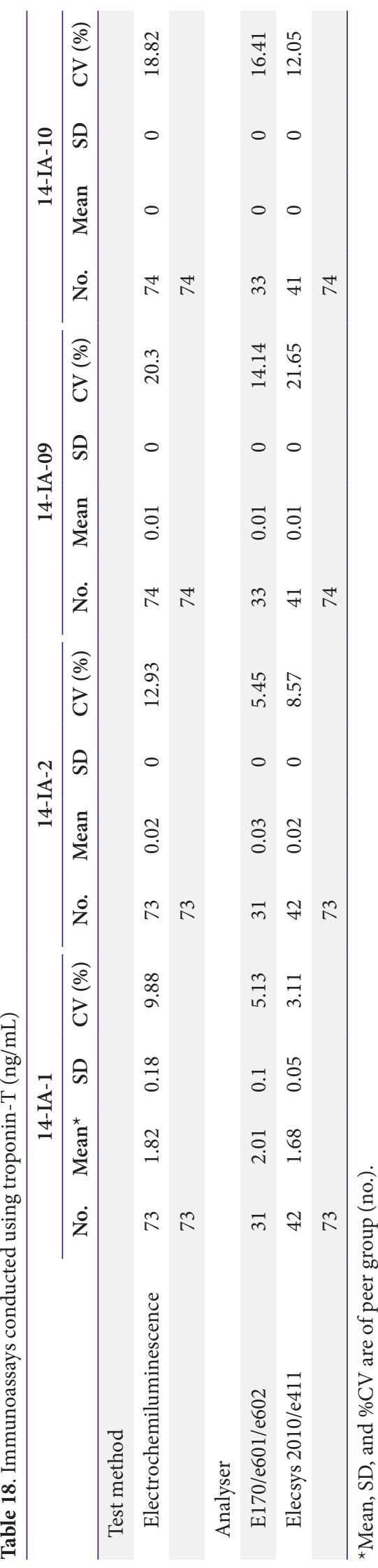

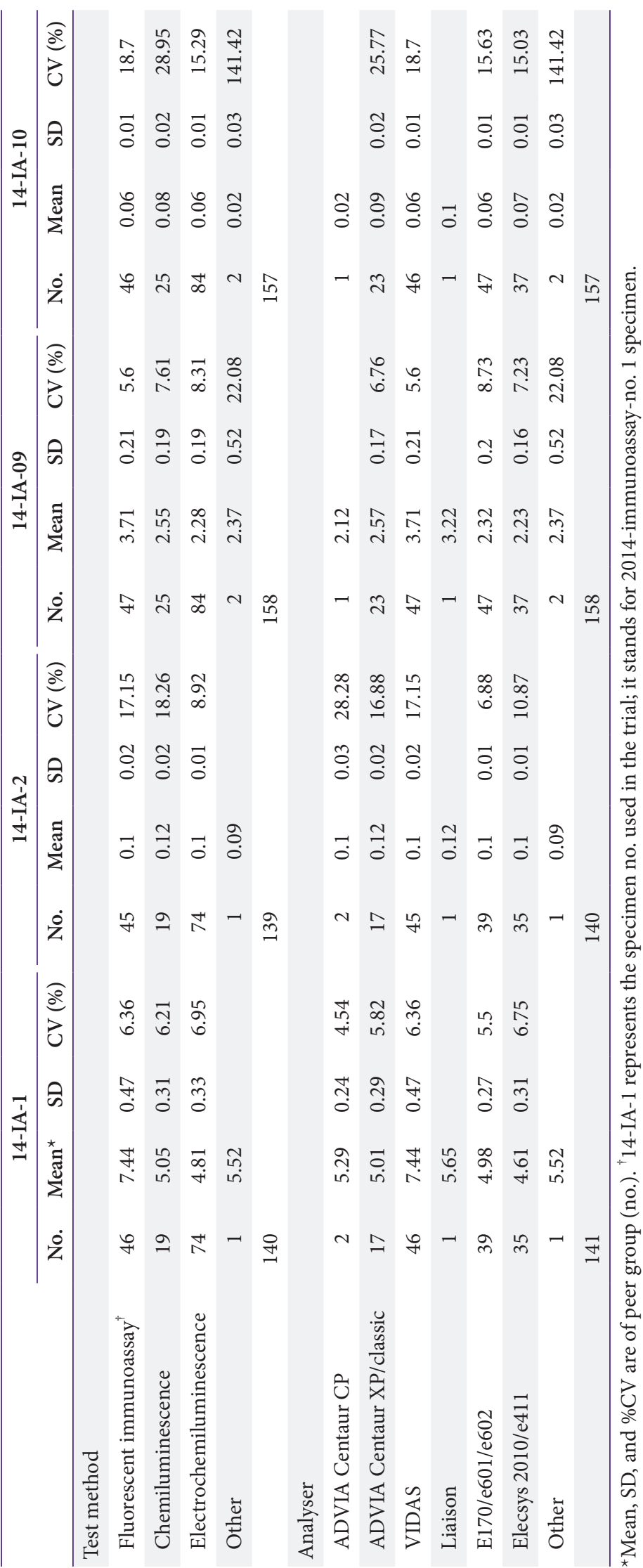

J Lab Med Qual Assur 2015;37:190-208 ～www.jlmqa.org 
Hyon-Suk Kim et al • EQA of Immunoassay Tests

\section{면역측정검사분과 위원(2014)}

김현숙(위원장, 연세대학교 의과대학 세브란스병원), 김영 란(간사, 연세의료원 세브란스병원), 임환섭(가톨릭관동대학 교 의과대학), 원동일(칠곡경북대학교병원), 박정용(연세의료 원 세브란스병원), 정순호(연세대학교 의과대학 강남세브란스 병원), 김혜련(국민건강보험공단 일산병원), 장호은(분당서울 대학교병원), 임승택(서울아산병원), 조윤정(고려대학교 의과 대학 안암병원), 남정현(인하대학병원)

\section{REFERENCES}

1. Kim HS, Kim YL; Immunoassay Subcommittee, The Korean Association of Quality Assurance for Clinical Laboratories. Annual report on external quality assessment of immunoassay testing in Korea (2013). J Lab Med Qual Assur 2014;36:171-89.

2. Kim HS, Kim YL, Park J, Kwon OH, Kim DA, Kim JQ, et al. Immunoassay external quality assessment of immunoassay subcommittee (2010). J Lab Med Qual Assur 2011;33(Suppl):S91-114.

3. Kim HS, Kim YL, Park J, Kwon OH, Kim DA, Kim JQ, et al. Annual report on external quality assessment in immunoassay in Korea (2009). J Lab Med Qual Assur 2010;32:103-14.

4. Cha YJ, Kwon SY, Kim TY, Kim JR, Kim HS, Park MH, et al. Annual report on external quality assessment in immunoserology in Korea (2008). J Lab Med Qual Assur 2009;31:49-72.

5. Kim HS, Kim YL, Lim HS, Park J, Chun HS, Shin S, et al. Annual report on external quality assessment of Immunoassay Subcommittee in Korean Clinical Laboratory Survey (2007). J Lab Med Qual Assur 2008;30:111-32.

6. Kim HS, Kim YL, Lim HS, Chun HS, Shin S, Jung YS, et al. Annual report on external quality assessment of Immunoassay Subcommittee in Korean Clinical Laboratory Survey (2006). J Lab Med Qual Assur 2007;29:99-119.

7. Kim HS. Immunoassay external quality control of immunoassays. J Lab Med Qual Assur 2003;25(S2): S38791.

8. Kim HS, Lim HS, Kwon OH, Kim DA, Kim YK, Kim YR, et al. Annual report on external quality assessment of immunoassay in Korea (2001). J Clin Pathol Qual Control 2002;24:83-94.

9. Kwon OH, Lim HS, Kim HS, Kim DA, Kim YK, Kim JQ, et al. Annual report on external quality assessment in immunoassay in Korea (2000). J Clin Pathol Qual Control 2001;23:111-44.

10. Kim HS. Future trends of immunoassay EQA. J Clin Pathol Qual Control 2001;23:S275-6.

11. Bock JL. The new era of automated immunoassay. Am J Clin Pathol 2000;113:628-46.

12. Ritchie RF. Immunoanalytical standardization: a global science. Scand J Clin Lab Invest Suppl 1991;205:3-10.

13. Whicher JT. Calibration is the key to immunoassay but the ideal calibrator is unattainable. Scand J Clin Lab Invest Suppl 1991;205:21-32.

14. Wood WG. "Matrix effects" in immunoassays. Scand J Clin Lab Invest Suppl 1991;205:105-12.

15. Tahlan A, Barrowcliff e T, Das RG, Shin J, Wood D. WHO technical workshop on stability of reference materials for biological medicines and in vitro diagnostics, Geneva, Switzerland, 28-29 November 2005. Biologicals 2007;35:361-5.

16. Jenny RW, Jackson-Tarentino KY. Causes of unsatisfactory performance in proficiency testing. Clin Chem 2000;46:89-99.

17. Kwon OH, Lim HS, Kim HS, Kim DU, Kim YK, Kim JQ, et al. Annual report on external quality assessment in immunoassay in Korea (1995). J Clin Pathol Qual Control 1996;18:95-117.

18. Kim HS. Internal quality control of immunochemistry tests. J Clin Pathol Qual Control 1993;15:S147-51.

19. Feldkamp CS, Carey JL. Standardization of immunoassay methodologies. In: Rose NR, Hamilton RG, Detrick B, editors. Manual of clinical laboratory immunology. 6th ed. Washington (DC): ASM Press, 2002: 1215-26.

20. College of American Pathologists. Standards for laboratory accreditation: Laboratory Accreditation Program 1998 edition. http://www.cap.org (Accessed December 2, 2015).

21. Miyai K, Price CP. Problems for improving performance in immunoassay. J Int Fed Clin Chem 1992;4:154-63. 


\section{면역측정검사분과 신빙도조사 결과보고(2014)}

\section{김현숙・김영란 • 대한임상검사정도관리협회 면역측정검사분과위원회}

연세대학교 의과대학 진단검사의학교실

2014년도 면역측정검사분과에서는 2회에 걸쳐 각 8종씩, 총 16종의 관리물질을 1차 712 기관, 2 차 715 기관에 대해서 신빙도조사를 실시하였다. 1회와 2회째 모두 갑상선호르몬 검사용 관리물질은 높 은 결과치를 보이는 혈청을 수집하기 어려웠기 때문에 상품화된 제품을 구입하여 사용하였고, 그 외 의 관리물질은 자가제조 하였다. 결과 회신율은 1 차와 2 차 모두 $97.9 \%$ 이었다. 검사결과의 분석 및 보고방법은 평균, 표준편차, 변이계수 등으로 분석하였으며, 참여 기관에서 사용하고 있는 방법과 장 비에 따라 기기별로 분류하여 peer group 결과를 분석하였다. 협회에서 전산화가 잘 되어 있어서 우 리 분과의 외부신빙도조사 결과 입력은 물론, 전체 방법과 기기별 통계, 그리고 협회 홈페이지에서 인 터넷을 이용하여 각 기관의 결과지 출력까지 가능하게 되었다. 현재 참여기관들에서 가장 많이 사용 되는 면역측정법은 자동화된 화학발광면역장비들이었는데, 이들 자동화 장비들이 대개 고유 원리와 시약을 사용하고 있어서 서로 결과치가 다를 수 있고 정확한 결과를 위해서는 장비와 사용자에 따른 정도관리가 지속적으로 필요한 것으로 판단되었다. 또한 지금까지와 마찬가지로 전국적인 신빙도조 사 사업 참여를 통해 검사의 질을 높여 나가야 할 것으로 생각되었다.

(J Lab Med Qual Assur 2015;37:190-208)

교신저자: 김현숙

우)03722 서울시 서대문구 연세로 50-1, 연세대학교 의과대학 진단검사의학교실

Tel: 02)2228-2443, Fax: 02)364-1583, E-mail: kimhs54@yuhs.ac 